\title{
IMPLEMENTASI METODE ELECTRE DALAM PENENTUAN KARYAWAN BERPRESTASI (STUDI KASUS: PT. MEGARIMAS SENTOSA)
}

\author{
Mesran $^{1}$, Selpi Anita ${ }^{2}$, Ronda Deli Sianturi ${ }^{3}$ \\ STMIK Budi Darma, Medan, Indonesia \\ Jalan Sisingamangaraja No. 338 Medan, Indonesia
}

\begin{abstract}
One of the important things that an employee must have is not separated from the performance of an employee. For the effectiveness of human resources work in the assessment of the right decision is needed. Therefore, the software is made that can take a decision to recommend employee achievement for PT. Megariamas Sentosa. The software is built on the basis of a decision support system that has the ability to select outstanding employees using the ELECTRE method. This Electre method has criteria that can determine alternative decisions in application in the software. So that decision makers can determine the selection of outstanding employees. The process in this Electre method compares employees with one employee to another and gives out put value of priority intensity in the form of the assessment result / criteria that has been specified by the company to the employee. The result of this process is recommended as an outstanding employee in PT. Megaria Mas Sentosa.
\end{abstract}

Keywords: Electre method, Employee Achievement

\begin{abstract}
Abstrak
Salah satu hal penting yang harus di miliki oleh seorang karyawan tidak lepas dari kinerja seorang karyawan. Demi efektifitas kerja SDM dalam penilaian pengambilan keputusan yang tepat sangat di perlukan. Oleh karena itu, di buat lah perangkat lunak yang dapat mengambil sebuah keputusan untuk merekomendasi karyawan berprestasi untuk PT. Megariamas Sentosa. Perangkat lunak ini di bangun dengan basis sistem pendukung keputusan yang memiliki kemampuan untuk memilih karyawan berprestasi dengan menggunakan metode ELECTRE. Metode Electre ini memiliki kriteria yg bisa menentukan alternatif keputusan dalam penerapan di perangkat lunak. Sehingga pembuat keputusan dapat menentukan pemilihan karyawan berprestasi. Proses dalam metode Electre ini membandingkan karyawan satu dengan karyawan yang lain dan memberikan out put nilai intensitas prioritas berupa hasil penilain/kriteria yang telah di tentukan oleh perusahaan tersebut terhadap karyawan. Hasil proses ini direkomendasi sebagai karyawan berprestasi di PT. Megaria Mas Sentosa.
\end{abstract}

Kata Kunci: Metode Electre, Karyawan Berprestasi

\section{PENDAHULUAN}

Manajemen Sumber Daya Manusia (MSDM) adalah suatu proses menangani berbagai masalah pada ruang lingkup karyawan, pegawai, manajer dan tenaga lainnya untuk dapat menunjang aktivitas organisasi perusahaan demi mencapai tujuan yang telah ditentukan. Salah satu elemen dalam perusahaan yang sangat penting adalah Sumber Daya Manusia (SDM). SDM dari suatu perusahaan sangat mempengaruhi banyak aspek penentu keberhasilan kerja dari perusahaan tersebut. Prestasi kerja adalah suatu bentuk dari hasil kerja seorang karyawan, hasil kerja tersebut nantinya akan dinilai oleh atasan maupun perusahaan. Tentunya jika seorang karyawan mendapatkan prestasi yang baik dia akan mendapatkan reward atau hadiah dari perusahaan tempat dimana ia bekerja. Prestasi kerja seorang karyawan tidak selamanya baik, ada yang bagus dan ada juga yang buruk. Maka dari itu setiap karyawan suatu organisasi atau perusahaan pasti akan berusaha untuk 
mendapatkan hasil kerja yang baik. Kualitas kerja seorang karyawan sangatlah berpengaruh dalam prestasi karyawan perusahaan. Yang dimana hal inilah yang menjadi pertimbangan seorang atasan atau manajer dalam memberikan penilaian. Kualitas yang dimaksud adalah pada saat melakukan kegiatan kerja, seorang karyawan mampu menunjukan kualitas SDM yang dimilikinya dengan memberikan kontribusi yang maksimal terhadap perusahaan tempat ia bekerja.

PT. Megariamas Sentosa melakukan pemilihan karyawan berprestasi untuk memacu karyawan dalam meningkatkan dedikasi dan kinerjanya. Pemilihan karyawan berprestasi dilakukan periodik yaitu setahun sekali tetapi belum optimal pelaksanaannya. PT. Megariamas Sentosa mendapat kendala dalam memutuskan pemilihan karyawan berprestasi yang akan diprioritaskan. PT. Megariamas Sentosa dalam pemilihan karyawan berprestasi masih menggunakan sistem manual. Hal ini sangat tidak efesien karena banyaknya karyawan yang harus dinilai. Selain itu, sering kali pihak manager atau atasan mengalami kesulitan untuk memilih karyawan yang berprestasi.

Penelitian ini bertujuan untuk mengetahui prosedur penilaian dalam pemilihan karyawan berprestasi pada PT. Megariamas Sentosa serta untuk menghasilkan sistem pendukung keputusan pemilihan karyawan berprestasi berdasarkan kriteria-kriteria yang telah ditentukan oleh PT. Megariamas Sentosa. Dalam menentukan karyawan berprestasi pada PT. Megariamas Sentosa menggunakan sistem pendukung keputusan dengan metode Elimination and Choice Translation Reality (ELECTRE).

Sistem pendukung keputusan pada dasarnya adalah bentuk pemilihan dari berbagai alternatif keputusan yang mungkin dipilih dimana prosesnya melalui mekanisme tertentu dengan harapan akan menghasilkan sebuah keputusan yang dianggap paling terbaik dari beberapa alternatif yang ada dengan kriteria yang telah ditentukan[1][2][3]-[5]. Dari sekian banyaknya metode sistem pendukung keputusan salah satunya adalah metode ELECTRE (Elimination and Choice Translation Reality)[6]. Metode ini dapat digunakan untuk mengambil keputusan dengan multi kriteria dan multi alternatif[7].

\section{METODOLOGI PENELITIAN}

\subsection{Karyawan Berprestasi}

Mendapatkan penghargaan atas prestasi karena kerja kerasnya merupakan suatu kebanggaan tersendiri.Tidak dipungkiri bahwa banyak orang bekerja keras untuk mengejar prestasi. Karena dengan prestasi akan membuka jalan untuk mengembangkan karirnya. Disisi lain setiap perusahaan tidak menutup mata akan memberikan reward atau hadiah kepada karyawan yang memberikan kontribusi positif terhadap perusahaannya. Bentuk penghargaan ini bermacam-macam, ada yang berbentuk kenaikan pangkat, promosi jabatan dan lain-lain.

Predikat "Karyawan Berprestasi" layak diberikan kepada karyawan yang bekerja secara sungguh-sungguh untuk meraih kesuksesan.Meskipun sukses bukanlah merupakan tujuan, tetapi sebuah perjalanan yang panjang. Untuk bisa lolos dan lulus dibutuhkan faktor penting yang mendampinginya yaitu kesabaran dan keuletan. 


\subsection{Elimination Et Choix Traduisant la Realite (ELECTRE)}

ELECTRE merupakan salah satu metode pengambilan keputusan salah satu metode pengambilan keputusan yang multikriteria berdasarkan pada konsep outranking dengan menggunakan perbandingan berpasangan dari alternatifalternatif berdasarkan setiap kriteria yang sesuai[6]. Metode ELECTRE digunakan pada kondisi dimana alternatif yang kurang sesuai dengan kriteria akan dieliminasi, dan alternatif yang sesuai dapat dihasilkan, dengan kata lain ELECTRE digunakan untuk kasus-kasus dengan banyak alternatif. Namun, hanya sedikit kriteria yang dilibatkan. Suatu alternatif dikatakan mendominasi alternatif yang lainnya jika satu atau lebih kriterianya melebihi (dibandingkan dengan kriteria dari alternatif yang lain) dan sama dengan kriteria lain yang tersisa.

Langkah-langkah yang dilakukan dalam penyelesaian masalah menggunakan metode ELECTRE[8][6] sebagai berikut :

1. Normalisasi matriks keputusan dalam prosedur ini, setiap atribut diubah menjadi nilai yang compareable. Setiap normalisasi rij dapat dilakukan dengan persamaan berikut :

$\mathrm{rij}=\frac{\mathrm{Xij}_{\mathrm{ij}}}{\sqrt{\sum_{\mathrm{i}}^{\mathrm{m}}=\mathrm{x}_{\mathrm{ij}}^{2}}}$

untuk $i=1,2,3, \ldots . . m$ dan $j=1,2,3, \ldots, n$

Keterangan:

rij = normalisasi pengukuran pilihan dari alternatif dan kriteria.

$\mathrm{m}=$ Alternatif

$\mathrm{n}=$ Kriteria.

Sehingga didapat matriks $\mathrm{R}$ hasil normalisasi :

$\mathrm{R}=\left[\begin{array}{cccc}\mathrm{r} 11 & \mathrm{r} 12 & \ldots & \mathrm{r} 1 \mathrm{n} \\ \mathrm{r} 21 & \mathrm{r} 22 & \ldots & \mathrm{r} 2 \mathrm{n} \\ \mathrm{rm} 1 & \mathrm{rm2} & \ldots & \mathrm{rmn}\end{array}\right]$

$\mathrm{R}$ adalah matriks yang telah dinormalisasi atau $\mathrm{m}$ disebut matriks yang telah dinormalized decision matrix. Dimana m menyatakan alternatif, $\mathrm{n}$ menyatakan kriteria dan rij adalah normalisasi pengukuran pilihan i dari alternatif ke-dalam hubungannya dengan $\mathrm{j}$ kriteria $\mathrm{ke}-\mathrm{j}$.

2. Pembobotan pada matriks yang telah dinormalisasikan.

Setelah dinormalisasikan, setiap kolom dari R matriks dikalikan dengan bobotbobot (Wj) yang ditentukan oleh pembuat keputusan . sehingga, wighted normalized matrix adalah

$\mathrm{V}=\mathrm{R}_{\mathrm{ij}} \mathrm{W}_{\mathrm{j}}$ 


$$
\mathrm{V}=\left[\begin{array}{cccc}
\mathrm{v} 11 & \mathrm{v} 12 & \ldots & \mathrm{v} 1 \mathrm{n} \\
\mathrm{v} 21 & \mathrm{v} 22 & \ldots & \mathrm{v} 2 \mathrm{n} \\
\ldots & \ldots & \ldots & \ldots \\
\mathrm{vm} 1 & \mathrm{vm} 2 & \ldots & \mathrm{vmn}
\end{array}\right]=\mathrm{RW}=\left[\begin{array}{cccc}
\mathrm{w} 1 \mathrm{r} 11 & \mathrm{w} 2 \mathrm{r} 12 & \ldots & \mathrm{wn} 1 \mathrm{n} \\
\mathrm{w} 1 \mathrm{r} 21 & \mathrm{w} 2 \mathrm{r} 22 & \ldots & \mathrm{wnr} 2 \mathrm{n} \\
\ldots & \ldots & \ldots & \ldots \\
\mathrm{w} 1 \mathrm{rm} 1 & \mathrm{w} 2 \mathrm{rm} 2 & \ldots & \text { wnrmn }
\end{array}\right]
$$

Dimana W adalah :

$$
\mathrm{W}=\left[\begin{array}{cccc}
\mathrm{w} 1 & 0 & \ldots & 0 \\
0 & \mathrm{w} 2 & \ldots & \\
\ldots & \ldots & \ldots & \ldots \\
0 & 0 & \ldots & \mathrm{wn}
\end{array}\right] \text {, dan } \sum_{\mathrm{i}=1}^{\mathrm{n}} \mathrm{w}=1
$$

3. Menentukan Concordance dan Discordance Index

Untuk setiap pasang dari alternatif $k$ dan $l(k \cdot l=1,2,3, \ldots, \mathrm{m}$ dan $\mathrm{k} \neq 1)$ kumpulan kriteria J dibagi menjadi dua subsets, yaitu concordance dan discordance. Bilamana sebuah kriteria dalam satu alternatif termasuk concordance adalah :

$\mathrm{Ckl}=\{\mathrm{j}, \mathrm{vkj} \geq \mathrm{vij}\}$

untuk j $=1,2,3, \ldots, n$

Sebaliknya, komplementer dari subset ini adalah discordance, yaitu bila :

$\operatorname{Dkl}=\{\mathrm{j}, \mathrm{kkj}<v i j\}$

untuk $\mathrm{j}=1,2,3, \ldots, \mathrm{n}$

Keterangan :

$\mathrm{Ckl}=$ himpunan concordance .

Dkl = himpunan discordance.

$\mathrm{Vkj}=$ indeks dari matriks $\mathrm{V}$.

$\mathrm{Vij}=$ indeks dari matriks $\mathrm{V}$.

4. Hitung matriks concordance dan discordance

a. Concordance

Untuk menentukan nilai dari elemen-elemen pada matriks concordance adalah dengan menjumlahkan bobot-bobot yang termasuk dalam subset concordance :

$\mathrm{Ckl}=\sum \mathrm{jcw} \mathrm{Wj}$

Sehingga matriks concordance yang dihasilkan adalah :

$$
\mathrm{C}=\left[\begin{array}{ccccc}
- & \mathrm{C} 12 & \mathrm{C} 13 & \ldots & \mathrm{C} 1 \mathrm{n} \\
\mathrm{C} 21 & \ldots & \mathrm{C} 23 & \ldots & \mathrm{C} 2 \mathrm{n} \\
\ldots & \ldots & \ldots & \ldots & \ldots \\
\mathrm{Cm} 1 & \mathrm{Cm} 2 & \mathrm{Cm} 3 & \ldots & -
\end{array}\right]
$$


b. Discordance

Untuk menentukan nilai dari elemen-elemen pada matriks discordance adalah dengan membagi maksimun selisih nilai kriteria yang termasuk dalam subset discordance dengan maksimum selisih nilai seluruh kriteria yang ada, secara matematisnya adalah :

$\mathrm{dkl}=\frac{\{\max (\mathrm{vmn}-\mathrm{vmn}-\mathrm{ln})\}, \mathrm{m}, \mathrm{n}, \in \mathrm{dklv}}{\{\max (\mathrm{vmn}-\mathrm{vln})\}, \mathrm{m}, \mathrm{n}=1,23\}}$

(6)

Selanjutnya diperoleh matriks discordance :

$\mathrm{D}=\left[\begin{array}{ccccc}- & \mathrm{d} 12 & \mathrm{~d} 13 & \ldots & \mathrm{d} 1 \mathrm{n} \\ \mathrm{d} 21 & \ldots & \mathrm{d} 23 & \ldots & \mathrm{d} 2 \mathrm{n} \\ \ldots & \ldots & \ldots & \ldots & \ldots \\ \mathrm{dm} 1 & \mathrm{dm} 2 & \mathrm{dm} 3 & \ldots & -\end{array}\right]$

5. Menentukan matriks dominan concordance dan discordance

a. Concordance

Matriks dominan concordance dapat dibangun dengan bantuan nilai threshold, yaitu dengan membandingkan setiap nilai elemen matriks concordance dengan nilai threshold.

$$
\mathrm{Ckl} \geq \underline{\mathrm{c}}
$$

Dengan nilai threshold $\underline{\underline{c}}$ adalah :

$$
\underline{\mathrm{c}}=\frac{\sum_{\mathrm{k}=1}^{\mathrm{n}} \sum_{\mathrm{l}=1}^{\mathrm{n}} \mathrm{ckl}}{\mathrm{m} *(\mathrm{~m}-1)}
$$

Dan setiap elemen matriks $F$ sebagai matriks dominan concordance ditentukan sebagai berikut :

$$
\mathrm{Fkl}=1 \text {, jika } \mathrm{Ckl} \geq \underline{\mathrm{c}} \text { dan } \mathrm{fkl}=0, \text { jika } \mathrm{Ckl}<\underline{\mathrm{c}}
$$

b. Discordance

Untuk membangun matriks dominan discordance juga menggunakan bantuan nilai threshold, yaitu :

$\underline{\mathrm{d}}=\frac{\sum_{\mathrm{k}=1}^{\mathrm{n}} \sum_{\mathrm{l}=1}^{\mathrm{n}} \mathrm{dkl}}{\mathrm{m} *(\mathrm{~m}-1)}$

Dan nilai setiap elemen untuk matriks G sebagai matriks dominan discordance ditentukan sebagai berikut:

$\mathrm{Gkl}=1$, jika $\mathrm{dkl} \geq \underline{d}$ dan $\mathrm{gkl}=0$, jika $\mathrm{dkl}<\underline{d}$ 
6. Menentukan aggregate dominance matrix

Langkah selanjutnya adalah menentukan aggregate dominance matrix sebagai matriks $E$, yang setiap elemennya merupakan perkalian antara elemen matriks $F$ dengan elemen matriks $G$, sebagai berikut :

$\mathrm{ekl}=\mathrm{fkl} * \mathrm{gkl}$

7. Eliminasi alternatif yang less favourable

Matriks $E$ memberikan urutan pilihan dari setiap alternatif, yaitu bila $e k l=1$ maka alternatif $A k$ merupakan pilihan yang lebih baik daripada Ar sehingga baris dalam matriks $E$ yang memiliki jumlah $e k l=1$ paling sedikit dapat dieliminasi.

Dengan demikian alternatif terbaik adalah yang mendominasi alternatifnya.

\section{HASIL DAN PEMBAHASAN}

Sistem yang berjalan saat ini, perusahaan mendapatkan hasil yang kurang optimal dalam mengambil keputusan. Dari masalah pengambilan keputusan yang ada, telah dianalisa permasalahannya untuk membuat sistem yang baru yang lebih efektif diharapkan mampu mengatasi permasalahan dalam pengambilan keputusan untuk memilih pegawai sesuai dengan kriteria-kriteria yang sudah ditentukan.Sistem pendukung keputusan pemilihan karyawan berprestasi diharapkan dapat membantu perusahaan dalam proses pemilihan pegawai terbaik di PT Megariamas Sentosa.

Berikut adalah data pegawai yang mengikuti seleksi untuk karyawan berprestasi. Berikut nama daftar pegawai yang menjadi alternatif untuk dijadikan perhitungan dengan mengambil sampel beberapa orang pegawai. Berikut ini merupakan daftar pegawai yang mengikuti seleksi:

Tabel 1. Daftar Pegawai

\begin{tabular}{|l|l|l|}
\hline No & Nama Karyawan & Kabupaten /Kota \\
\hline 1 & Selvi Anita & Medan \\
\hline 2 & Khaidah Hanum & Medan \\
\hline 3 & Nur Aisyah & Medan \\
\hline
\end{tabular}

Dalam Proses metode ELECTRE memerlukan kriteria-kriteria yang akan dijadikan bahan perhitungan dan pertimbangan untuk penyeleksian tersebut. Adapun kriteria-kriteria yang menjadi bahan perhitungan dan pertimbangan dapat dilihat pada table.

Tabel 2. Kriteria

\begin{tabular}{|l|l|}
\hline Kriteria & Keterangan \\
\hline C1 & Kerajinan \\
\hline C2 & Kehadiran \\
\hline C3 & Omset Personality \\
\hline C4 & Growth Penjualan \\
\hline
\end{tabular}

Dari masing-masing kriteria tersebut akan ditentukan bobot-bobotnya. Dan setiap kriteria pada bobot akan diberikan nilai sebagai berikut: 
Tabel 3. Nilai Bobot Kriteria

\begin{tabular}{|c|l|}
\hline Bilangan Bulat & \multicolumn{1}{|c|}{ Keterangan } \\
\hline 1 & Sangat Rendah \\
\hline 2 & Rendah \\
\hline 3 & Cukup \\
\hline 4 & Tinggi \\
\hline 5 & Sangat Tinggi \\
\hline
\end{tabular}

Berdasarkan kriteria dan rating kecocokan setiap alternatif pada setiap kriteria yang telah ditentukan, kriteria yang digunakan dalam pemilihan pegawai terbaik adalah sebagai berikut:

1. Kerajinan

Seorang pegawai harus selalu memiliki kerajinan baik itu dalam segi waktu atau pun dalam bentuk tenaga untuk dapat bersaing dengan pegawai lainnya.

Tabel 4. Kriteria Kerajinan

\begin{tabular}{|l|l|l|}
\hline Kerajinan (C1) & Keterangan & Nilai \\
\hline Sangat Tidak Rajin & Sangat Rendah & $0-20$ \\
\hline Tidak Rajin & Rendah & $21-40$ \\
\hline Cukup Rajin & Cukup & $41-60$ \\
\hline Rajin & Tinggi & $61-80$ \\
\hline Sangat Rajin & Sangat Tinggi & $81-100$ \\
\hline
\end{tabular}

2. Kehadiran

Seorang pegawai yang ingin terpilih harus memiliki tingkat kehadiran yang baik. Dalam hal ini proses penyeleksian hanya dilakukan untuk mencari pegawai dengan kehadiran yang maksimal untuk menjadi karyawan berprestasi di perusahaan ini.

Tabel 5. Kriteria Kehadiran

\begin{tabular}{|l|l|l|}
\hline Kehadiran (C2) & Keterangan & Nilai \\
\hline Sangat Tidak Baik & Sangat Rendah & $0-20$ \\
\hline Tidak Baik & Rendah & $21-40$ \\
\hline Cukup Baik & Cukup & $41-60$ \\
\hline Baik & Tinggi & $61-80$ \\
\hline Sangat Baik & Sangat Tinggi & $81-100$ \\
\hline
\end{tabular}

3. Omset Personality

Seorang pegawai juga diharus untuk menghasilkan Omset Personality yang banyak.

Tabel 6. Kriteria Omset Personality

\begin{tabular}{|l|l|l|}
\hline Omset Personality (C3) & Keterangan & Nilai \\
\hline Sangat Tidak Baik & Sangat Rendah & $0-20$ \\
\hline Tidak Baik & Rendah & $21-40$ \\
\hline Cukup Baik & Cukup & $41-60$ \\
\hline Baik & Tinggi & $61-80$ \\
\hline Sangat Baik & Sangat Tinggi & $81-100$ \\
\hline
\end{tabular}

4. Growth Penjualan 
Seorang pegawai harus memiliki Growth Penjualan yang baik pula untuk menjadi karyawan berprestasi.

Tabel 7. Kriteria Growth Penjualan

\begin{tabular}{|c|c|c|}
\hline Growth Penjualan (C4) & Keterangan & Nilai \\
\hline Sangat Tidak Baik & Sangat Rendah & $0-20$ \\
\hline Tidak Baik & Rendah & $21-40$ \\
\hline Cukup Baik & Cukup & $41-60$ \\
\hline Baik & Tinggi & $61-80$ \\
\hline Sangat Baik & Sangat Tinggi & $81-$ \\
& & 100 \\
\hline
\end{tabular}

Beberapa alternatif yang dijadikan sebagai contoh perhitungan di dalam pemilihan pegawai terbaik seperti berikut:

Tabel 8. Alternatif Untuk Kriteria

\begin{tabular}{|c|l|}
\hline Kriteria & Keterangan \\
\hline A1 & Selvi Anita \\
\hline A2 & Khaidah Hanum \\
\hline A3 & Nur Aisyah \\
\hline
\end{tabular}

Berikut tabel rating kecocokan dari setiap alternatif pada kriteria yang sudah ditentukan.

Tabel 9. Rating Kecocokan dari setiap alternatif

\begin{tabular}{|c|c|c|c|c|}
\hline \multirow{2}{*}{ Alternatif } & \multicolumn{4}{|c|}{ Kriteria } \\
\cline { 2 - 5 } & C1 & C2 & C3 & C4 \\
\hline A1 & 90 & 90 & 70 & 60 \\
\hline A2 & 80 & 90 & 88 & 80 \\
\hline A3 & 90 & 80 & 60 & 80 \\
\hline
\end{tabular}

Tabel 10. Penyederhanaan Rating Kecocokan

\begin{tabular}{|c|c|c|c|c|}
\hline \multirow{2}{*}{ Alternatif } & \multicolumn{4}{|c|}{ Kriteria } \\
\cline { 2 - 5 } & C1 & C2 & C3 & C4 \\
\hline A1 & 5 & 5 & 4 & 3 \\
\hline A2 & 4 & 5 & 5 & 4 \\
\hline A3 & 5 & 4 & 3 & 4 \\
\hline
\end{tabular}

Tabel 10 Menunjukkan rating kecocokan dari setiap alternatif disetiap kriteria. Nilai terbesar adalah nilai terbaik, maka semua kriteria yang diberikan diasumsikan sebagai kriteria keuntungan. Pengambilan keputusan memberikan bobot preferensi sebagai berikut:

Tabel 11. Bobot $w$

\begin{tabular}{|c|c|}
\hline Keterangan & Bobot W \\
\hline Kerajinan & $0.15 \%$ \\
\hline Kehadiran & $0.15 \%$ \\
\hline Omset Personality & $0.50 \%$ \\
\hline
\end{tabular}




\begin{tabular}{|c|c|}
\hline Keterangan & Bobot W \\
\hline Growth Penjualan & $0.20 \%$ \\
\hline
\end{tabular}

Sehinggga $W=(0.15,0.15,0.50,0.20)$

Matrix keputusan yang dibentuk dari table kecocokan adalah sebagai berikut:

$x=\left[\begin{array}{llll}5 & 5 & 4 & 3 \\ 4 & 5 & 5 & 4 \\ 5 & 4 & 3 & 4\end{array}\right]$

Untuk menyelesaikan masalah diatas dengan metode ELECTREakan dilakukan sesuai dengan langkah-langkah yang telah dijelaskan.

1. Normalisasi matriks keputusan(1).

$$
\begin{array}{ll}
\left|\mathrm{x}_{1}\right|=\sqrt{5^{2}+4^{2}+5^{2}}=8.124 & \left|\mathrm{x}_{3}\right|=\sqrt{4^{2}+5^{2}+3^{2}}=7.071 \\
r_{11}=\frac{\mathrm{X}_{11}}{\left|\mathrm{X}_{1}\right|}=\frac{5}{8.124}=0.615 & r_{13}=\frac{\mathrm{X}_{13}}{\left|\mathrm{X}_{3}\right|}=\frac{4}{7.071}=0.566 \\
r_{21}=\frac{\mathrm{X}_{21}}{\left|\mathrm{X}_{1}\right|}=\frac{4}{8.124}=0.492 & r_{23}=\frac{\mathrm{X}_{23}}{\left|\mathrm{X}_{3}\right|}=\frac{5}{7.071}=0.707 \\
r_{31}=\frac{\mathrm{X}_{31}}{\left|\mathrm{X}_{1}\right|}=\frac{5}{8.124}=0.615 & r_{33}=\frac{\mathrm{X}_{33}}{\left|\mathrm{X}_{3}\right|}=\frac{3}{7.071}=0.424 \\
\left|\mathrm{X}_{2}\right|=\sqrt{5^{2}+5^{2}+4^{2}}=8.124 & \left|\mathrm{x}_{4}\right|=\sqrt{3^{2}+4^{2}+4^{2}}=6.403 \\
r_{12}=\frac{\mathrm{X}_{12}}{\left|\mathrm{X}_{2}\right|}=\frac{5}{8.124}=0.615 & r_{14}=\frac{\mathrm{X}_{14}}{\left|\mathrm{X}_{4}\right|}=\frac{3}{6.403}=0.468 \\
r_{22}=\frac{\mathrm{X}_{22}}{\left|\mathrm{X}_{2}\right|}=\frac{5}{8.124}=0.615 & r_{24}=\frac{\mathrm{X}_{24}}{\left|\mathrm{X}_{4}\right|}=\frac{4}{6.403}=0.624 \\
r_{32}=\frac{\mathrm{X}_{32}}{\left|\mathrm{X}_{2}\right|}=\frac{4}{8.124}=0.492 & r_{34}=\frac{\mathrm{X}_{34}}{\left|\mathrm{X}_{4}\right|}=\frac{5}{6.403}=0.780
\end{array}
$$

Dari perhitungan diatas diperoleh mariks $\mathrm{R}$

$$
R=\left[\begin{array}{llll}
0.615 & 0.615 & 0.566 & 0.468 \\
0.492 & 0.615 & 0.707 & 0.624 \\
0.615 & 0.492 & 0.424 & 0.780
\end{array}\right]
$$

2. Pembobotan pada matriks yang telah dinormalisasi.

$$
\mathrm{V}=\mathrm{RW}=\left[\begin{array}{llll}
0.615 & 0.615 & 0.566 & 0.468 \\
0.492 & 0.615 & 0.707 & 0.624 \\
0.615 & 0.492 & 0.424 & 0.780
\end{array}\right] \cdot\left[\begin{array}{llll}
0.15 & 0.15 & 0.50 & 0.20
\end{array}\right]
$$

Hasilnya seperti berikut ini. 


$$
V=\left[\begin{array}{llll}
0.092 & 0.092 & 0.283 & 0.094 \\
0.074 & 0.092 & 0.353 & 0.125 \\
0.092 & 0.074 & 0.212 & 0.156
\end{array}\right]
$$

3. Menentukan himpunan concordance dan disdordance index.

a. Concordance

Himpunan concordance index dihitung berdasarkan(3).

$$
\begin{aligned}
& \mathrm{K}=1 \quad \mathrm{i}=1 \mathrm{C}_{11} \text { identitas }=\{1,2,3,4\} \\
& \mathrm{i}=2 \mathrm{C}_{12} \\
& j=1 \text { jika } V_{11} \geq V_{21}=0.092 \geq 0.074 \text { ya } j=1 \\
& j=2 \text { jika } V_{12} \geq V_{22}=0.092 \geq 0.092 \text { ya } j=2 \\
& \mathrm{j}=3 \text { jika } \mathrm{V}_{13} \geq \mathrm{V}_{23}=0.283 \geq 0.353 \text { tidak } \\
& \mathrm{j}=4 \text { jika } V_{14} \geq V_{24}=0.094 \geq 0.125 \text { tidak } \\
& \mathrm{C}_{12}=\{1,2\} \\
& \mathrm{i}=3 \mathrm{C}_{13} \\
& \mathrm{j}=1 \text { jika } \mathrm{V}_{11} \geq \mathrm{V}_{31}=0.092 \geq 0.092 \text { ya } \mathrm{j}=1 \\
& j=2 \text { jika } V_{12} \geq V_{32}=0.092 \geq 0.074 \text { ya } j=2 \\
& \mathrm{j}=3 \text { jika } V_{13} \geq V_{33}=0.283 \geq 0.212 \text { ya } \mathrm{j}=3 \\
& \mathrm{j}=4 \text { jika } \mathrm{V}_{14} \geq \mathrm{V}_{34}=0.094 \geq 0.156 \text { tidak } \\
& \mathrm{C}_{13}=\{1,2,3\} \\
& \mathrm{K}=2 \quad \mathrm{i}=1 \mathrm{C}_{21} \\
& \mathrm{j}=1 \text { jika } \mathrm{V}_{21} \geq \mathrm{V}_{11}=0.074 \geq 0.092 \text { tidak } \\
& \mathrm{j}=2 \text { jika } \mathrm{V}_{22} \geq \mathrm{V}_{12}=0.092 \geq 0.092 \text { ya } \mathrm{j}=2 \\
& j=3 \text { jika } V_{23} \geq V_{13}=0.353 \geq 0.283 \text { ya } j=3 \\
& \mathrm{j}=4 \text { jika } \mathrm{V}_{24} \geq \mathrm{V}_{14}=0.125 \geq 0.094 \text { ya } \mathrm{j}=4 \\
& \mathrm{C}_{21}=\{2,3,4\} \\
& \mathrm{i}=1 \mathrm{C}_{22} \text { identitas }=\{1,2,3,4\} \\
& \mathrm{i}=3 \mathrm{C}_{23} \\
& \mathrm{j}=1 \text { jika } \mathrm{V}_{21} \geq \mathrm{V}_{31}=0.074 \geq 0.092 \text { tidak } \\
& \mathrm{j}=2 \text { jika } \mathrm{V}_{22} \geq \mathrm{V}_{32}=0.092 \geq 0.074 \text { ya } \mathrm{j}=2 \\
& \mathrm{j}=3 \text { jika } \mathrm{V}_{23} \geq \mathrm{V}_{33}=0.353 \geq 0.212 \text { ya } \mathrm{j}=3 \\
& \mathrm{j}=4 \text { jika } \mathrm{V}_{24} \geq \mathrm{V}_{34}=0.125 \geq 0.156 \text { tidak } \\
& \mathrm{C}_{23}=\{2,3\} \\
& \mathrm{K}=3 \quad \mathrm{i}=1 \mathrm{C}_{31} \\
& \mathrm{j}=1 \text { jika } \mathrm{V}_{31} \geq \mathrm{V}_{11}=0.092 \geq 0.092 \text { ya } \mathrm{j}=1 \\
& \mathrm{j}=2 \text { jika } V_{32} \geq V_{12}=0.074 \geq 0.092 \text { tidak } \\
& \mathrm{j}=3 \text { jika } V_{33} \geq V_{13}=0.212 \geq 0.283 \text { tidak } \\
& \mathrm{j}=4 \text { jika } \mathrm{V}_{34} \geq \mathrm{V}_{14}=0.156 \geq 0.094 \text { ya } \mathrm{j}=4 \\
& \mathrm{C}_{31}=\{1,4\} \\
& \mathrm{i}=2 \mathrm{C}_{32} \\
& \mathrm{j}=1 \text { jika } V_{31} \geq V_{21}=0.092 \geq 0.074 \text { ya } \mathrm{j}=1 \\
& \mathrm{j}=2 \text { jika } V_{32} \geq V_{22}=0.074 \geq 0.092 \text { tidak } \\
& \mathrm{j}=3 \text { jika } V_{33} \geq V_{23}=0.212 \geq 0.353 \text { tidak } \\
& \mathrm{j}=4 \text { jika } \mathrm{V}_{34} \geq \mathrm{V}_{24}=0.156 \geq 0.125 \text { ya } \mathrm{j}=4 \\
& \mathrm{C}_{32}=\{1,4\} \\
& \mathrm{i}=3 \mathrm{C}_{33} \text { identitas }=\{1,2,3,4\}
\end{aligned}
$$

b. Discordance 
Himpunan discordance index dihitung berdasarkan(4).

$$
\begin{aligned}
& \mathrm{K}=1 \quad \mathrm{i}=1 \mathrm{D}_{11} \text { identitas }=\{\} \\
& \mathrm{i}=2 \mathrm{D}_{12} \\
& \text { j=1 jika } V_{11}<V_{21}=0.092<0.074 \text { tidak } \\
& \mathrm{j}=2 \text { jika } \mathrm{V}_{12}<\mathrm{V}_{22}=0.092<0.092 \text { tidak } \\
& \mathrm{j}=3 \text { jika } \mathrm{V}_{13}<\mathrm{V}_{23}=0.283<0.353 \text { ya } \mathrm{j}=3 \\
& \mathrm{j}=4 \text { jika } \mathrm{V}_{14}<\mathrm{V}_{24}=0.094<0.125 \text { ya } \mathrm{j}=4 \\
& D_{12}=\{3,4\} \\
& \mathrm{i}=3 \mathrm{D}_{13} \\
& \mathrm{j}=1 \text { jika } \mathrm{V}_{11}<\mathrm{V}_{31}=0.092<0.092 \text { tidak } \\
& \mathrm{j}=2 \text { jika } \mathrm{V}_{12}<\mathrm{V}_{32}=0.092<0.074 \text { tidak } \\
& \mathrm{j}=3 \text { jika } \mathrm{V}_{13}<\mathrm{V}_{33}=0.283<0.212 \text { tidak } \\
& \mathrm{j}=4 \text { jika } \mathrm{V}_{14}<\mathrm{V}_{34}=0.094<0.156 \text { ya } \mathrm{j}=4 \\
& \mathrm{D}_{13}=\{4\} \\
& \mathrm{K}=2 \quad \mathrm{i}=1 \mathrm{D}_{21} \\
& \mathrm{j}=1 \text { jika } \mathrm{V}_{21}<\mathrm{V}_{11}=0.074<0.092 \text { ya } \mathrm{j}=1 \\
& \mathrm{j}=2 \text { jika } \mathrm{V}_{22}<\mathrm{V}_{12}=0.092<0.092 \text { tidak } \\
& \mathrm{j}=3 \text { jika } \mathrm{V}_{23}<\mathrm{V}_{13}=0.353<0.283 \text { tidak } \\
& \mathrm{j}=4 \text { jika } \mathrm{V}_{24}<\mathrm{V}_{14}=0.125<0.094 \text { tidak } \\
& \mathrm{D}_{21}=\{1\} \\
& \mathrm{i}=2 \mathrm{D}_{22} \text { identitas }=\{\} \\
& \mathrm{i}=3 \mathrm{D}_{23} \\
& \mathrm{j}=1 \text { jika } \mathrm{V}_{21}<\mathrm{V}_{31}=0.074<0.092 \text { ya } \mathrm{j}=1 \\
& \mathrm{j}=2 \text { jika } \mathrm{V}_{22}<\mathrm{V}_{32}=0.092<0.074 \text { tidak } \\
& \mathrm{j}=3 \text { jika } \mathrm{V}_{23}<\mathrm{V}_{33}=0.353<0.212 \text { tidak } \\
& \mathrm{j}=4 \text { jika } \mathrm{V}_{24}<\mathrm{V}_{34}=0.125<0.156 \text { tidak } \\
& \mathrm{D}_{23}=\{1\} \\
& \mathrm{K}=3 \quad \mathrm{i}=1 \mathrm{D}_{31} \\
& \text { j=1 jika } V_{31}<V_{11}=0.092<0.092 \text { tidak } \\
& \mathrm{j}=2 \text { jika } V_{32}<V_{12}=0.074<0.092 \text { уа } \mathrm{j}=2 \\
& \mathrm{j}=3 \text { jika } \mathrm{V}_{33}<\mathrm{V}_{13}=0.212<0.283 \text { ya } \mathrm{j}=3 \\
& \mathrm{j}=4 \text { jika } \mathrm{V}_{34}<\mathrm{V}_{14}=0.156<0.094 \text { tidak } \\
& \mathrm{D}_{31}=\{2,3\} \\
& \mathrm{i}=2 \mathrm{D}_{32} \\
& \text { j=1 jika } V_{31}<V_{21}=0.092<0.074 \text { tidak } \\
& \mathrm{j}=2 \text { jika } \mathrm{V}_{32}<\mathrm{V}_{22}=0.074<0.092 \text { ya } \mathrm{j}=2 \\
& \mathrm{j}=3 \text { jika } \mathrm{V}_{33}<\mathrm{V}_{23}=0.212<0.353 \text { ya } \mathrm{j}=3 \\
& \mathrm{j}=4 \text { jika } \mathrm{V}_{34}<\mathrm{V}_{24}=0.156<0.125 \text { tidak } \\
& \mathrm{D}_{32}=\{2,3\} \\
& \mathrm{i}=3 \mathrm{D}_{33} \text { identitas }=\{\}
\end{aligned}
$$

4. Menghitung matriks concordance dan discordance.

a. Menghitung matriks concordance(5).

$$
\begin{aligned}
& C_{12}=w_{1}+w_{2}=0.15+0.15=0.30 \\
& C_{13}=w_{1}+w_{2}+w_{3}=0.15+0.15+0.50=0.80 \\
& C_{21}=w_{2}+w_{3}+w_{4}=0.15+0.50+0.20=0.85
\end{aligned}
$$




$$
\begin{aligned}
& C_{23}=w_{2}+w_{3}=0.15+0.50=0.65 \\
& C_{31}=w_{1}+w_{4}=0.15+0.20=0.35 \\
& C_{32}=w_{1}+w_{4}=0.15+0.20=0.35
\end{aligned}
$$

Jadi,matriks concordance adalah:

$C=\left[\begin{array}{ccc}-0.30 & 0.80 \\ 0.85 & -0.65 \\ 0.35 & 0.35\end{array}\right]$

b. Menghitung matriks discordance(6).

$$
\begin{aligned}
& D_{12}=\frac{\max \{|0.283-0.353| ;|0.094-0.125|\}}{\max \{|0.092-0.074| ;|0.092-0.092| ;|0.283-0.353| ;|0.094-0.125|\}} \\
& =\frac{\max \{0.07 ; 0.031\}}{\max \{0.018 ; 0 ; 0,07 ; 0,031\}} \\
& =\frac{0.07}{0.07}=1 \\
& D_{13}=\frac{\max \{0.094-0.156\}}{\max \{|0.092-0.092| ;|0.092-0.074| ;|0.283-0.212| ;|0.094-0.156|\}} \\
& =\frac{\max \{0.062\}}{\max \{0 ; 0.018 ; 0,071 ; 0,062\}} \\
& =\frac{0.062}{0.07}=0.885 \\
& D_{21}=\frac{\max \{0.074-0.092\}}{\max \{|0.074-0.092| ;|0.092-0.092| ;|0.353-0.283| ;|0.125-0.094|\}} \\
& =\frac{\max \{0.018\}}{\max \{0.018 ; 0 ; 0.07 ; 0,031\}} \\
& =\frac{0.018}{0.07}=0.26 \\
& D_{23}=\frac{\max \{0.074-0.092\}}{\max \{|0.074-0.092| ;|0.092-0.074| ;|0.353-0.212| ;|0.125-0.156|\}} \\
& =\frac{\max \{0.018\}}{\max \{0.018 ; 0.018 ; 0.141 ; 0.031\}} \\
& =\frac{0.018}{0.141}=0.13 \\
& D_{31}=\frac{\max \{0.074-0.092|;| 0.212-0.283\}}{\max \{|0.092-0.092| ;|0.074-0.092| ;|0.212-0.283| ;|0.156-0.094|\}} \\
& =\frac{\max \{0.018 ; 0.071\}}{\max \{0 ; 0.018 ; 0.071 ; 0.062\}} \\
& =\frac{0.071}{0.071}=1 \\
& D_{32}=\frac{\max \{0.074-0.092|;| 0.212-0.353\}}{\max \{|0.092-0.074| ;|0.074-0.092| ;|0.212-0.353| ;|0.156-0.125|\}} \\
& =\frac{\max \{0.018 ; 0.141\}}{\max \{0.018 ; 0.018 ; 0.141 ; 0.031\}}
\end{aligned}
$$


$=\frac{0.141}{0.141}=1$

Jadi matriks discordance adalah :

$$
\mathrm{D}=\left[\begin{array}{cc}
-1 & 0.885 \\
0.26 & -0.13 \\
1 & 1-
\end{array}\right]
$$

5. Menentukan matriks dominan concordance dan discordance.

a. Menghitung matriks dominan concordance

Nilai threshold (ㅁ) adalah(7)

$$
\begin{aligned}
\underline{C} & =\frac{0.30+0.80+0.85+0.65+0.35+0.35}{3(3-1)} \\
& =\frac{3.3}{6}=0.55
\end{aligned}
$$

Elemen matriks F ditentukan sebagai berikut:

$$
f_{k l}=\left\{\begin{array}{c}
1, \text { jika } c_{k l} \geq \underline{c} \\
0, \text { jika } c_{k l<\underline{c}}
\end{array}\right.
$$

Sehingga matriks dominan concordance adalah

$$
F=\left[\begin{array}{ccc}
- & 0 & 1 \\
1 & -1 \\
0 & 0 & -1
\end{array}\right]
$$

b. Menghitung matriks dominan discordance

Nilai threshold () adalah(8)

$$
\begin{aligned}
\underline{D} & =\frac{1+0.885+0.26+0.13+1+1}{3(3-1)} \\
& =\frac{4.275}{6}=0,7125
\end{aligned}
$$

Dan elemen matriks G ditentukan sebagai berikut:

$$
g_{k l}=\left\{\begin{array}{l}
1, j i k a c_{k l} \geq \underline{d} \\
0, j i k a c_{k l}<\underline{d}
\end{array}\right.
$$

Sehingga matriks dominan discordance adalah

$$
\mathrm{G}=\left[\begin{array}{ccc}
- & -1 & 1 \\
0 & - & 0 \\
1 & 1 & -
\end{array}\right]
$$

6. Menentukan aggregate dominance matriks.

Rumus umum untuk anggota matriks aggregate dominance adalah(9)

$$
\begin{aligned}
& e_{12}=f_{12} \times g_{12}=0 \times 1=0 \\
& e_{13}=f_{13} \times g_{13}=1 \times 1=1 \\
& e_{21}=f_{21} \times g_{21}=1 \times 0=1
\end{aligned}
$$


$e_{23}=f_{23} \times g_{23}=1 \times 0=1$

$e_{31}=f_{31} \times g_{31}=0 \times 1=0$

$e_{32}=f_{32} \times g_{32}=0 \times 1=0$

Sehingga matriks aggregate dominance adalah

$E=\left[\begin{array}{ccc}- & 0 & 1 \\ 1 & -1 \\ 0 & 0 & -\end{array}\right]$

7. Eliminasi alternatif yang less favourable.

Matriks E memberikan urutan pilihan dari setiap alternatif, yaitu bila $e_{k l}=1$ maka alternatif $A_{k}$ merupakan alternatif yang lebih baik dari pada $A_{1}$. Sehingga, baris dalam matriks E yang memiliki jumlah $e_{k l}=$ lebih banyak dapat dieliminasi. Dengan demikian, $A_{2}$ lebih baik dari $A_{1}$. $A_{2}$ jika dibandingkan dengan $A_{3}$, alternatif $A_{2}$ lebih baik dari $A_{1}$ karena memiliki jumlah angka 1 yang lebih banyak.

\section{SIMPULAN}

Kesimpulan yang diperoleh dari penelitian ini, yaitu:

a. Dalam melakukan perhitungannya, metode ELECTRE melakukan tiga dasar proses yaitu, memilih, menyortir dan memberi peringkat.

b. Penerapan metode ELECTRE dapat mengefisiensi proses seleksi calon mahasiswa pada calon mahasiswa penerima SNMPTN Jalur Undangan di Perguruan Tinggi Negeri.

\section{DAFTAR PUSTAKA}

[1] Kusrini, Konsep Dan Aplikasi Pemdukung Keputusan. Yogyakarta: Andi, 2007.

[2] G. Ginting, Fadlina, Mesran, A. P. U. Siahaan, and R. Rahim, "Technical Approach of TOPSIS in Decision Making," Int. J. Recent Trends Eng. Res., vol. 3, no. 8, pp. 58-64, 2017.

[3] T. Imandasari and A. P. Windarto, "Sistem Pendukung Keputusan dalam Merekomendasikan Unit Terbaik di PDAM Tirta Lihou Menggunakan Metode Promethee," J. Teknol. dan Sist. Komput., vol. 5, no. 4, p. 159, 2017.

[4] A. P. Windarto, "Penilaian Prestasi Kerja Karyawan PTPN III Pematangsiantar Dengan Metode Simple Additive Weighting (SAW)," J. Ris. Sist. Inf. Dan Tek. Inform., vol. 2, no. ISSN 2527-5771, pp. 84-95, 2017.

[5] Agus Perdana Windarto, "Implementasi metode topsis dan saw dalam memberikan reward pelanggan," Kumpul. J. Ilmu Komput., vol. 4, no. 1, pp. 88-101, 2017.

[6] M. Mesran, G. Ginting, S. Suginam, and R. Rahim, "Implementation of Elimination and Choice Expressing Reality ( ELECTRE) Method in Selecting the Best Lecturer ( Case Study STMIK BUDI DARMA )," Int. J. Eng. Res. Technol., vol. 6, no. 2, NaN-2017, pp. 141-144, 2017.

[7] S. Kusumadewi, S. Hartati, A. Harjoko, and R. Wardoyo, Fuzzy Multi-Attribute Decision Making (Fuzzy MADM). Yogyakarta: Graha Ilmu, 2006.

[8] I. Saputra, S. I. Sari, and Mesran, "Penerapan Elimination And Choice Translation Reality (Electre) Dalam Penentuan Kulkas Terbaik," KOMIK (Konferensi Nas. Teknol. Inf. dan Komputer), vol. I, pp. 295-305, 2017. 